\section{Right Atrial Myxoma Mimicking a Rheumatic Disorder}

\section{Brit. med. F., 1967, 1, 547-548}

Myxomas are the commonest intracardiac tumours. The clinical features are due to obstruction, emboli, or a general systemic disturbance. Usually the mechanical and embolic features predominate, and the condition has then the appearance of valvular heart disease or bacterial endocarditis. The generalized manifestations include fever, loss of weight, anaemia, a raised sedimentation rate, and plasma protein abnormalities. These features are usually less prominent, and their pathogenesis is not understood.

This report describes the case of a woman in which the systemic features were so prominent that she was initially thought to have a rheumatic disorder. Her serum was found to contain antibodies to heart muscle, and their possible significance is discussed.

\section{CASE REPORT}

A 38-year-old housewife had been well until December 1963. She then began to lose weight and complained of fatigue and generalized aching, and later of joint pains. In August 1964 she was admitted to her local hospital. Physical examination showed nothing of note. She was febrile and the erythrocyte sedimentation rate varied from 30 to $90 \mathrm{~mm}$. in the first hour, and she had a hypochromic anaemia with a haemoglobin of $10 \mathrm{~g} . / 100 \mathrm{ml}$. The plasma albumin was $3.4 \mathrm{~g} . / 100 \mathrm{ml}$. and the globulin was $4.2 \mathrm{~g} . /$ $100 \mathrm{ml}$. A course of phenylbutazone brought slight temporary relief.

In March 1965 she was admitted to the London Hospital. By this time she had lost $60 \mathrm{lb}$. $(27.2 \mathrm{~kg}$.) in weight, and the arthralgia was worse. At no time had she noticed swelling or discoloration

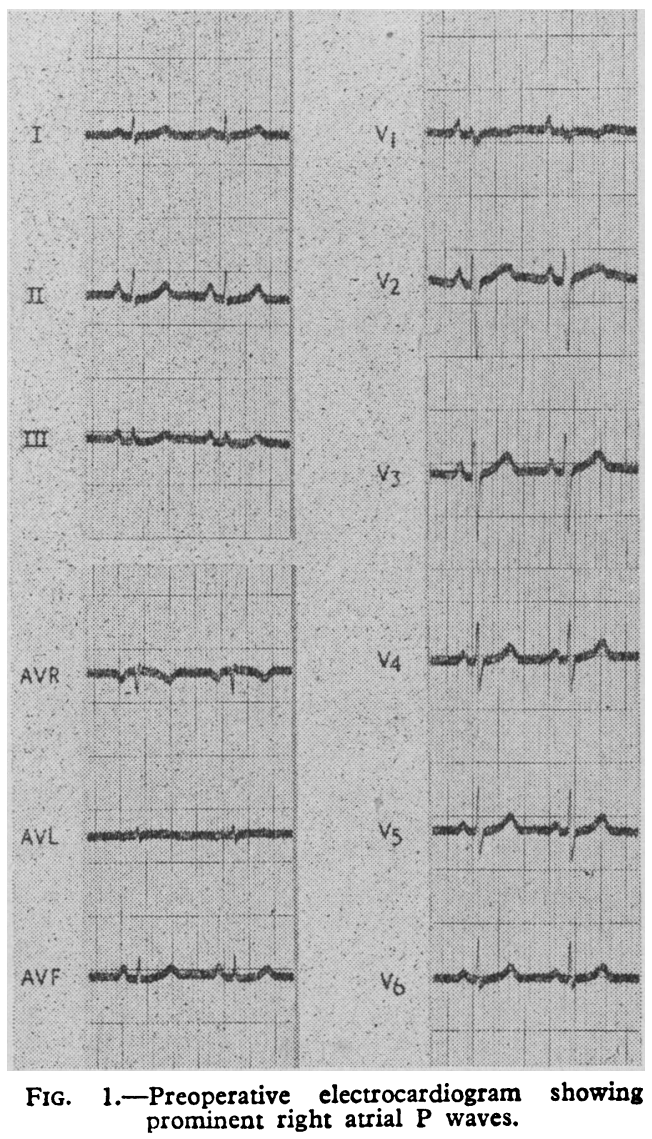

of her joints. She admitted to slight shortness of breath on hurrying and an occasional precordial ache, but there had been no cough, pleuritic pain, or fainting.

She was emaciated and had an intermittent fever to $103^{\circ} \mathrm{F}$. $\left(39.4^{\circ}\right.$ C.). Both knees were swollen, and the right contained a small effusion. She was tender over the lower sternum and fourth dorsal spinous process. Arterial pulses were normal and the blood pressure was $110 / 70 \mathrm{~mm}$. $\mathrm{Hg}$. The jugular venous pulse showed large " a" waves. The cardiac impulse was normal. At the lower end of the sternum tricuspid presystolic and diastolic murmurs were heard.

She had a hypochromic anaemia, with haemoglobin of $9.4 \mathrm{~g} . /$ $100 \mathrm{ml}$., a leucocyte count of $9,900 / \mathrm{cu}$. mm., and an erythrocyte sedimentation rate of $68 \mathrm{~mm}$. in the first hour. The plasma albumin was $4 \mathrm{~g}$. and globulin $3.9 \mathrm{~g} . / 100 \mathrm{ml}$. ; electrophoresis showed a slight increase in alpha-2 globulin and gammaglobulins. The alkaline phosphatase on two occasions was 17.2 and 30 K.A. units. Plasma levels of urea, uric acid, calcium, inorganic phosphorus, and electrolytes were normal. Blood cultures, L.E. cell tests, and antinuclear factor tests were negative, and urinary 5-hydroxyindole acetic acid excretion was normal. The latex test for rheumatoid factor was negative. $X$-ray films of the chest, bones, and joints showed
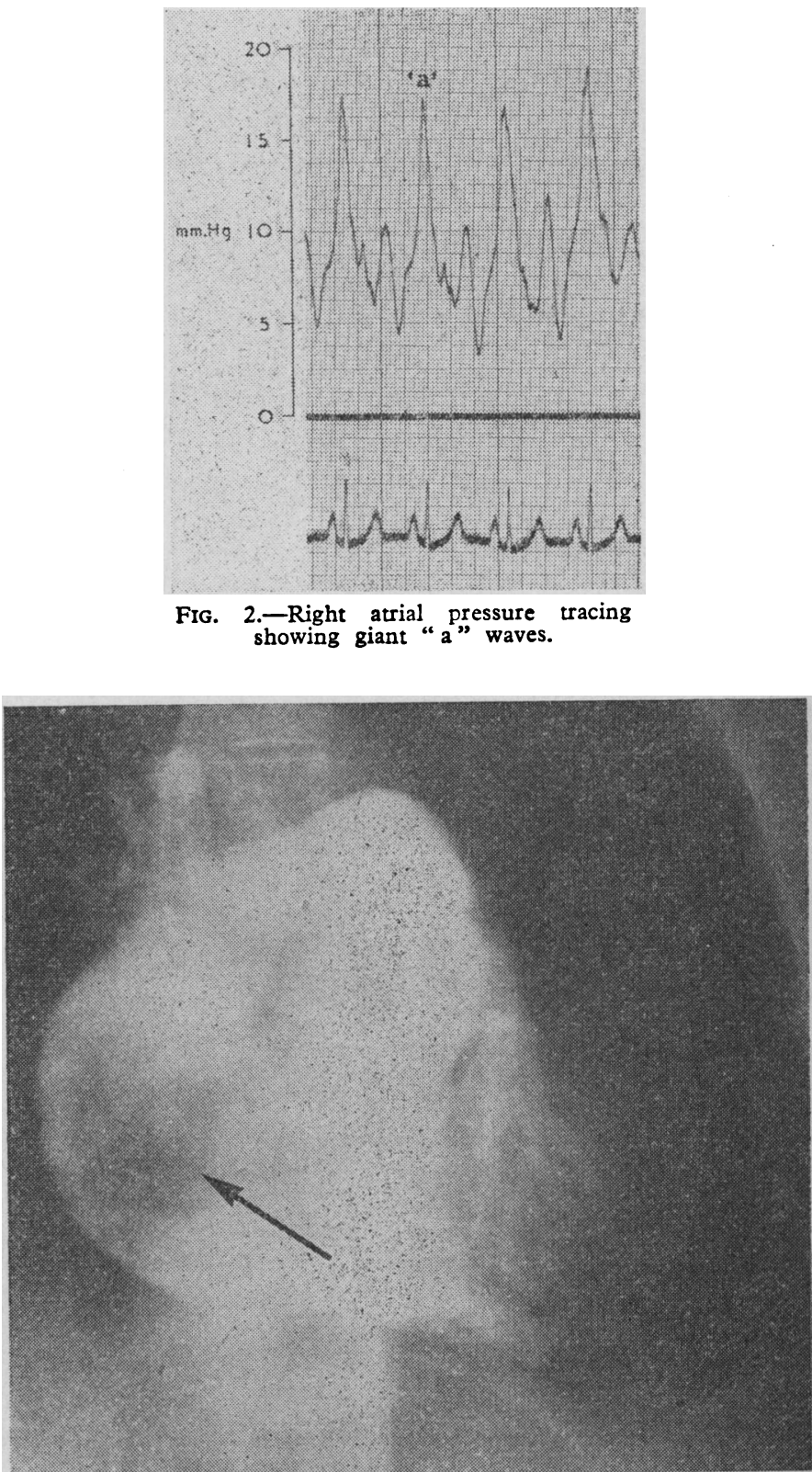

FIG. 3.-Postero-anterior view of a venous angiogram showing a large flling defect in the right atrium while the right ventricle and pulmonary arteries are well opacified. 
nothing abnormal. At this stage the patient had an episode of pleuritic pain, but a further chest $x$-ray film was clear.

Electrocardiography showed prominent right atrial $\mathbf{P}$ waves but no other abnormality (Fig. 1). Cardiac catheterization showed a raised right atrial pressure with a mean of $9 \mathrm{~mm}$. $\mathrm{Hg}$, and " $\mathrm{a}$ " waves of $16 \mathrm{~mm}$. $\mathrm{Hg}$ (Fig. 2). The pulmonary artery and right ventricular pressures were normal. There was a presystolic gradient across the tricuspid valve of $9 \mathrm{~mm}$. $\mathrm{Hg}$. A large filling defect in the right atrium extending into the right ventricle was shown by angiocardiography (Fig. 3).

The tumour (measuring 7 by $10 \mathrm{~cm}$.) was removed intact by $\mathrm{Mr}$. Donald Ross, using cardiopulmonary bypass and hypothermia. It arose by a small pedicle from the lateral wall of the right atrium, and protruded through the tricuspid valve. The postoperative course was complicated by an external iliac occlusion at the site of cannulation, treated surgically, and by an episode of fever and central chest pain with a pericardial friction rub. Five weeks after operation the patient was discharged; she had started to gain weight, the erythrocyte sedimentation rate was $8 \mathrm{~mm}$., and she was free of pain.

Four months postoperatively she was still symptom-free and had regained 2 stones $(12.7 \mathrm{~kg}$.) in weight. No abnormal cardiovascular signs were found, and her haemoglobin, erythrocyte sedimentation rate, plasma proteins, and alkaline phosphatase were normal.

Specimens of serum were collected preoperatively, and at 12 days and four months postoperatively. These specimens were tested for antibodies to human heart muscle, the myxoma, and human kidney by the tanned-red-cell test (Ehrenfeld et al., 1961) and anti-human globulin consumption test (see Table).

Results of Tanned-red-cell Test and Antt-human Globulin Test

\begin{tabular}{|c|c|c|c|}
\hline & \multirow{2}{*}{$\begin{array}{c}\text { Before } \\
\text { Operation }\end{array}$} & \multicolumn{2}{|c|}{ After Operation } \\
\hline & & 12 Days & 4 Months \\
\hline \multicolumn{4}{|c|}{ Tanned-red-cell Test } \\
\hline 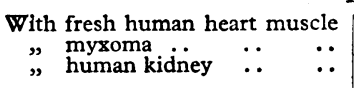 & $\begin{array}{l}\text { Pos. }(1 / 160) \\
\text { Negative } \\
\quad \text {, }\end{array}$ & $\begin{array}{l}\text { Pos. }(1 / 320) \\
\text { Negative } \\
y\end{array}$ & $\begin{array}{l}\text { Pos. }(1 / 40) \\
\text { Not done } \\
\text { Negative }\end{array}$ \\
\hline \multicolumn{4}{|c|}{ Anti-human Globulin Consumption Test } \\
\hline 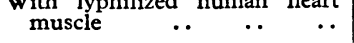 & Positive & Positive & Positive \\
\hline
\end{tabular}

Both tanned-red-cell and anti-human globulin consumption methods gave positive results on all three occasions with heart muscle antigen. With human kidney, all results were negative. Negative results were also obtained when myxoma tissue was used with the tanned-cell method.

\section{Discussion}

In this patient right atrial myxoma produced profound constitutional disturbances for 15 months before diagnosis. Constitutional effects are not uncommon with this tumour. In 45 cases of left atrial myxoma collected by Goodwin (1963) anaemia, fever, raised sedimentation rate, loss of weight, and abnormal serum proteins were each present in about half the patients. Systemic effects occurred in 4 of the 18 cases of right atrial myxoma reviewed by Morrissey et al. (1963).

When these features occur in association with changing cardiac murmurs and embolic phenomena, bacterial endocarditis is likely to be mimicked (Kirkeby and Leren, 1952; Barlow et al., 1962 ; Thomas et al., 1965). But patients in whom the constitutional disturbance is not accompanied by obvious cardiac signs or embolization are liable to be diagnosed as suffering from a connective-tissue disorder, especially when joint pains occur. This "rheumatic" presentation has been reported by Dixon (1965) and by Skanse et al. (1959). In both instances the patients had Raynaud's phenomenon, joint pains, and evidence of a constitutional disturbance. Both died of unsuspected left atrial myxomas. Other case reports mention joint symptoms probably not related to the myxoma (Fawcett and Ward, 1939 ; MacGregor and Cullen, 1959).

The mechanism by which atrial myxomas produce systemic disturbances is unknown. MacGregor and Cullen (1959) suggest that degeneration and haemorrhage within the tumour may be responsible, in the same way that degenerating uterine fibroids may produce general effects. Boss and Bechar (1959) suggest that this is an immune response to fragments of tumour released into circulation. Certainly this would explain the increase in immune globulins, and the clinical response to steroids reported by Catt et al. (1962). Our studies indicate that there was a disturbance of immunity in this patient, but we were unable to show that the myxoma was the source of the antigen.

Antibody reacting with heart muscle has been shown to occur in a high percentage of patients with postcardiotomy and postinfarction syndromes, and also in systemic lupus erythematosus (Robinson and Brigden, 1963, 1965). Our patient had a postcardiotomy syndrome, but the anti-heart antibodies were present in her serum even before operation. This would be consistent with a pre-existing autoimmune state, and lends weight to the argument that such a state was responsible for her constitutional disturbance.

There was no evidence of specific myocardial damage due to the antibody, and it seems likely that its presence was merely an indication of a more widespread autoimmune process. No antibodies to myxoma tissue were found (though we have no previous experience to judge the efficacy of the test when using myxoma as antigen).

It is possible that an intracardiac myxoma may initiate and maintain an autoimmune state analogous to that seen after cardiotomy or myocardial infarction. Operative removal in this patient seemed to correct the autoimmune disturbance.

We are grateful to Dr. M. H. K. Haggie and Dr. W. S. Tegner for permission to report cases under their care. It is a pleasure to thank Mr. Donald Ross for details of his operative procedure and Dr. W. W. Brigden for his help in preparing the paper.

\section{H. L. F. CURREY, M.MED., M.R.C.P.,}

J. A. MathewS, ${ }^{*}$ M.B., M.R.C.P., Departments of Physical Medicine and Rheumatology, the London Hospital.

J. RoBINSON, M.B., M.R.C.P.,

Cardiac Department, the London Hospital.

* Now at Department of Physical Medicine, St. Thomas's Hospital, London S.E.1.

\section{REFERENCES}

Barlow, J., Fuller, D., and Denny, M. (1962). Brit. Heart 7., 24, 120.

Boss, J. H., and Bechar, M. (1959). Amer. F. Cardiol., 3, 823.

Catt, K., Denborough, M. A., Grigg, L., and Sloman, G. (1962). Brit. Heart 7., 24, 525 .

Dixon, A. St. J. (1965). Progress in Clinical Rheumatology, p. 362. London.

Fhrenfeld E N. Gery, I., and Davies, A. M. (1961). Lancet, 1, 1138

Ehrenfeld, E. N., Gery, 1., and D. M. (1939). Brit. Heart F., 1, 249.

Fawcett, R. E. M., and Ward, E. M. 464

Goodwin, J. F. (1963). Lancet, 1, 464.

Kirkeby, K., and Leren, P. (1952). Acta med. scand., 143, 385.

MacGregor, G. A., and Cullen, R. A. (1959), Brit. med. F., 2, 991. Amer. Heart 9., 66, 4.

Robinson, J. F., and Brigden, W. W. (1963). Brit. med. F., 2, 706.

Robinson, (1965). Unpublished observations.

Skanse, B., Berg, N. O., and Westfelt, L. (1959). Acta med. scand., 164,

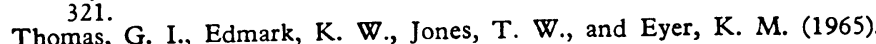
Northw. Med. (Seattle), 64, 41. 